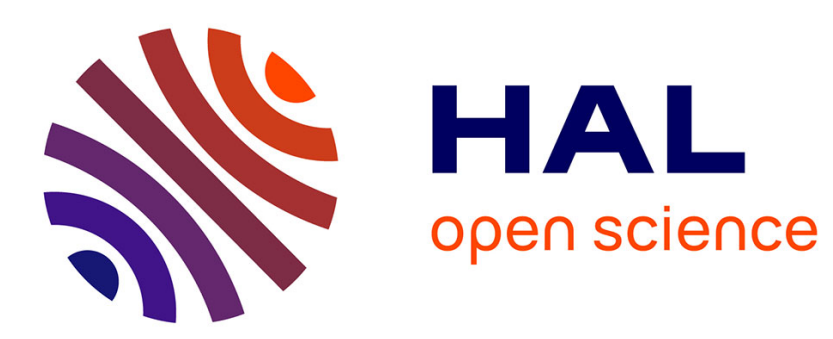

\title{
Synthesis of Barium Hexaferrite and Catalytic Behavior in the Combustion of Methane
}

\author{
A. Favre, N. Guilhaume, A. Pierre
}

\section{To cite this version:}

A. Favre, N. Guilhaume, A. Pierre. Synthesis of Barium Hexaferrite and Catalytic Behavior in the Combustion of Methane. Journal de Physique IV Proceedings, 1997, 07 (C1), pp.C1-675-C1-676. 10.1051/jp4:19971276 . jpa-00254988

\section{HAL Id: jpa-00254988 https://hal.science/jpa-00254988}

Submitted on 1 Jan 1997

HAL is a multi-disciplinary open access archive for the deposit and dissemination of scientific research documents, whether they are published or not. The documents may come from teaching and research institutions in France or abroad, or from public or private research centers.
L'archive ouverte pluridisciplinaire HAL, est destinée au dépôt et à la diffusion de documents scientifiques de niveau recherche, publiés ou non, émanant des établissements d'enseignement et de recherche français ou étrangers, des laboratoires publics ou privés. 


\title{
Synthesis of Barium Hexaferrite and Catalytic Behavior in the Combustion of Methane
}

\author{
A. Favre, N. Guilhaume and A. Pierre \\ Université Claude Bernard - Lyon I, LACE, UMR 5634 du CNRS, Bât. 303, \\ 43 boulevard du 11 Novembre 1918, 69622 Villeurbanne cedex, France
}

\begin{abstract}
Barium hexaferrite doped with iridium was synthesized by two methods: the citrate gel and the polyacrylamide gel methods. The nature of phases obtained and the specific surface area were determined after heat treatments in air at $700^{\circ} \mathrm{C}, 900^{\circ} \mathrm{C}$ and in air containing $10 \%$ humidity at $1200^{\circ} \mathrm{C}$. The catalytic activity in the combustion of methane was measured after heat treatment at $900^{\circ} \mathrm{C}$. These hexaferrites showed a good catalytic activity after treatment at $900^{\circ} \mathrm{C}$ However this catalytic activity and the specific surface disappeared after heat treatment at $1200^{\circ} \mathrm{C}$.
\end{abstract}

\section{INTRODUCTION AND EXPERIMENTAL PROCEDURE}

In a recent study, it was shown that $\mathrm{BaAl}_{12} \mathrm{O}_{19}$ doped with $\mathrm{Fe}$ or $\mathrm{Mn}$ presents interesting catalytic properties for the clean combustion of hydrocarbons [1]. In the present study, we focused on $\mathrm{BaFe}_{12} \mathrm{O}_{19}$ doped with Ir. Such materials were synthesized from barium acetate and hydrated ferric nitrate according to 2 methods. In the first method, gelation was achieved by evaporation at $\approx 70^{\circ} \mathrm{C}$ and $\mathrm{pH}=7$ with $\mathrm{NH}_{4} \mathrm{OH}$, after complexation with 2 moles of citric acid per mole of cation. In the second method, only 1 mole citric acid per mole of + charge was used, and gelation was achieved by adding $\approx 12 \mathrm{~g}$ of acrylamide and $0.5 \mathrm{~g}$ of $\mathrm{N}, \mathrm{N}^{\prime}$-methylene bisacrylamide to $\approx 200 \mathrm{~mL}$ of the solution. Polymerization of acrylamide was initiated by adding $50 \mathrm{mg}$ of azo-bis-isobutyronitrile (AIBN) and $\approx 0.05 \mathrm{~mL}$ of $\mathrm{N}, \mathrm{N}, \mathrm{N}^{\prime}, \mathrm{N}^{\prime}$-tetramethylenediamide (TEMED) dissolved in $\approx 4 \mathrm{~mL}$ ethanol. Gelation occurred at $\approx 90^{\circ} \mathrm{C}$ in a few minutes. Samples containing $1 \%$ and $5 \%$ iridium by mass were made by adding iridium acetylacetonate in acetone before gelation. However, at $5 \%$ iridium with the polyacrylamide, precipitation of Ir in the solution was obvious.

All gels were calcined at $\approx 500^{\circ} \mathrm{C}$. Some samples were heated $3 \mathrm{~h}$ in air at $700^{\circ} \mathrm{C}$. Other samples were treated similarly at $\mathrm{T}=900^{\circ} \mathrm{C}$. A third set of samples were treated at $1200^{\circ} \mathrm{C}$ for 24 hours, in air containing $10 \%$ humidity. After each thermal treatment, the specific surface of these materials was measured by the Brunauer, Emmett and Teller (BET) method and the nature of phases was determined by powder X-ray diffraction. Catalytic tests were achieved on fixed powder bed reactors containing $\approx 0.5 \mathrm{~g}$ of ferrite, crossed by a through flow of a gas mixture composed of $1 \%$ methane, an over-stoichiometric proportion of oxygen for the combustion of methane, and nitrogen. The total flow rate at room temperature under 1 bar was $\approx 6.4 \mathrm{~L} \mathrm{~h}^{-1}$. The temperature was progressively increased by increments of $50{ }^{\circ} \mathrm{C}$, from $350{ }^{\circ} \mathrm{C}$ up to $800{ }^{\circ} \mathrm{C}$. At each temperature, a holding time of $3 \mathrm{~h}$ was maintained, and the proportions of $\mathrm{CH}_{4}, \mathrm{CO}_{2}$ and $\mathrm{CO}$ in the exit gas were analyzed in a chromatograph, at regular time intervals of $30 \mathrm{~min}$.

\section{EXPERIMENTAL RESULTS}

The temperature where the hexaferrite phase was formed depended on the fabrication procedure. At $700^{\circ} \mathrm{C}$ in samples containing no $\mathrm{Ir}$, the polyacrylamide route led to $\mathrm{Fe}_{2} \mathrm{O}_{3}$ as the major phase, while in the samples made by the citrate route $\mathrm{Fe}_{2} \mathrm{O}_{3}$ was a minor phase (Fig. 1). Also, the relative intensity at $700^{\circ} \mathrm{C}$ of the $\mathrm{Fe}_{2} \mathrm{O}_{3}$ diffraction peaks, with respect to the $\mathrm{BaFe}_{12} \mathrm{O}_{19}$ peaks, was roughly independent of the Ir content in samples made by the citrate method, while it drastically decreased as the Ir content increased in the samples made by the polyacrylamide method. After heat treatment at $900^{\circ} \mathrm{C}$ all samples showed the same X- Ray powder diffraction pattern where the only observable phase was $\mathrm{BaFe}_{12} \mathrm{O}_{19}$. The specific surface area is rerported in Fig. 2. It was roughly independent of Ir content in samples made by the citrate technique, while it increased significantly with the Ir content in samples made by the polyacrylamide technique. After aging at $1200^{\circ} \mathrm{C}$ in the presence of humidity, all samples had lost their porosity.

The ferrites synthesized at $900^{\circ} \mathrm{C}$ in the present study showed a good catalytic activity, with $100 \%$ selectivity in $\mathrm{CO}_{2}$. For instance, as shown in Fig. 3, the T10 temperature (10\% conversion temperature) was about $80^{\circ} \mathrm{C}$ lower for the best hexaferrite without Ir than for $\mathrm{BaMn}_{2} \mathrm{Al}_{10} \mathrm{O}_{19}$ [2]. This catalytic activity was relatively independent of the Ir content in the citrate 
samples, while it improved gradually with the Ir content in the polyacrylamide samples. After treatment at $1200^{\circ} \mathrm{C}$ in wet air, this activity virtually disappeared.

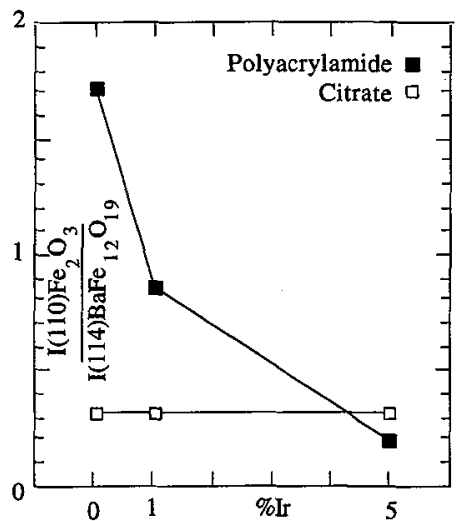

Figure 1: Intensity ratio of diffraction peaks (110) for $\mathrm{Fe}_{2} \mathrm{O}_{3}$ and (114) for $\mathrm{BaFe}_{12} \mathrm{O}_{19}$, at $700^{\circ} \mathrm{C}$.

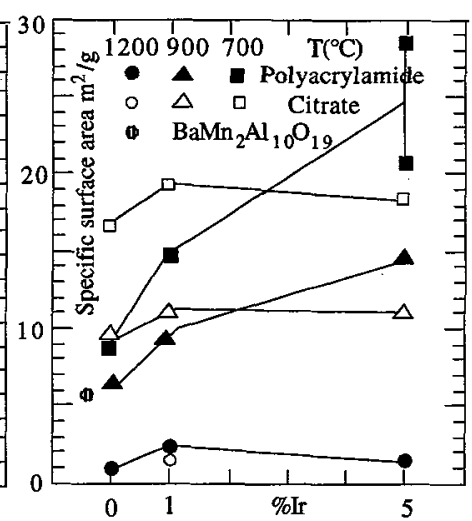

Figure 2: Specific surface area of ferrite samples $\left(\mathrm{m}^{2} / \mathrm{g}\right)$ and $\mathrm{BaMn}_{2} \mathrm{Al}_{10} \mathrm{O}_{19}$ from [2]

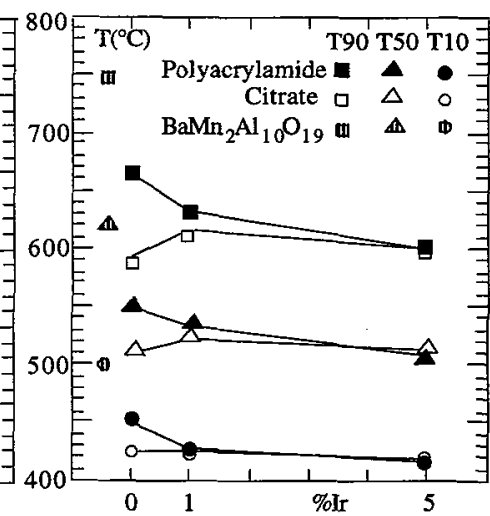

Figure 3: Temperatures for $10 \%$ (T10), $50 \%$ (T50) and 90\% conversion (T90), in the combustion of methane

\section{DISCUSSION}

The present study showed a drastic relation between the catalytic activity at $900^{\circ} \mathrm{C}$, the specific surface area, and the proportion of barium hexaferrite formed at $700^{\circ} \mathrm{C}$. In samples made by the citrate route, the phase transformation, specific surface area and catalytic activity were independent of the Ir content. On the other hand, in samples made by the polyacrylamide route, the formation, specific surface area and catalytic activity of barium hexaferrite improved as the Ir content increased. Using polyacrylamide was detrimental to the catalytic activity, but this was progressively balanced by addition of Ir. The polyacrylamide sample with $5 \%$ Ir, as well as all samples made by the citrate route, had roughly a similar and good catalytic activity.

The ionic radii of $\mathrm{Fe}^{3+}$ and $\mathrm{Ir}^{4+}$ are very similar to each other, respectively 0.0645 and $0.0625 \mathrm{~nm}$ [3]. For instance, Vincent et al. [4] synthesized similar M-type $\mathrm{Zn}$ and Co hexaferrites doped with Ir, where Ir mostly substituted for Fe. However, it is well known that the formation path of a complex phase is often influenced by the fabrication procedure. In the present study, the lower specific area and the higher $\mathrm{Fe}_{2} \mathrm{O}_{3} \mathrm{X}$-ray peaks intensity in the polyacrylamide sample containing no $\mathrm{Ir}$ at $700^{\circ} \mathrm{C}$, by comparison with the citrate sample containing no Ir (Fig.1), suggests that relatively big hematite grains were formed when using polyacrylamide. Moreover, only when using the polyacrylamide route, precipitation of dark Ir crystals was observed upon addition of the Ir precursor in the solution. This was not observed in the citrate route. The fine precipitated Ir crystals in the polyacrylamide samples may possibly have hindered the growth of hematite grains. This resulted in a shorter diffusion path to form the hexaferrite phase more easily, and simultaneously increased the specific surface area. In the hexaferrite made via the citrate route, Ir may possibly have substituted for $\mathrm{Fe}$.

Because one of the most active sample was made by the citrate route and contained no Ir, it appears that the catalytic activity which we observed was due to the hexaferrite phase. A comparison of Fig. 2 and Fig. 3 shows that this catalytic activity roughly increased with the specific area, so that it was independent of the Ir content in the citrate samples while it improved with the Ir content in the polyacrylamide samples. This observation is also consistent with the simultaneous collapse of the catalytic activity and specific surface area after treatment at $1200^{\circ} \mathrm{C}$ in humid air.

\section{CONCLUSION}

Barium hexaferrite is an active material to catalyze the combustion of methane. Its pore structure lacks thermal stability. However, adding Ir had a significant influence on the phase formation and specific surface area at $900^{\circ} \mathrm{C}$ in the polyacrylamide process. This suggests that other additives may be able to hinder the sintering of the hexaferrite at temperatures as high as $1200^{\circ} \mathrm{C}$. Hence, the synthesis of a ferrite potentially as good as the hexaaluminate with respect to thermal stability and with a much better catalytic activity, appears to be possible.

\section{References}

[1] Machida M., Eguchi K., Arai H. , Chem. Letters (Japan) (1986) 1993-1996.

[2] Machida M., Eguchi K., Arai H. , Chem. Letters (Japan) (1987) 767-770.

[3] Shannon R.D., Acta Crist., A32 (1976) 751-767.

[4] Vincent H., Brando E., Sugg B. , J. Solid State Chem., 120 (1995) 17-22. 